\title{
METODE PEMBELAJARAN MATEMATIKA YANG MENYENANGKAN \& TEPAT UNTUK OTAK KANAN PADA SISWA JURUSAN SENI MUSIK DI SMK KHUSUS BIDANG KESENIAN
}

\author{
Priyo Abhi Sudewo \\ Mahasiswa Magister Sains Psikologi, Universitas Surabaya
}

\begin{abstract}
Abstrak
Materi pelajaran matematika sangat penting bagi kehidupan, namun sebagian pelajar Indonesia menganggap materi pelajaran matematika adalah materi pelajaran yang sulit dan membosankan, oleh karena itu mengakibatkan berkurangnya kesenangan (joy) dan kebahagiaan (happiness) dalam menjalani pelajaran matematika pada sebagian siswa di Indonesia. Selain itu beberapa siswa memiliki gaya belajar yang berbeda-beda seperti belajar diiringi dengan melihat video penjelasan ilmiahnya atau siswa-siswa yang tidak mampu memahami suatu pelajaran jika tidak diajak untuk mempraktekannya secara langsung di dunia nyata (tidak sekedar abstraksi dalam pikiran semata). Peran guru yang kurang optimal dalam memahami gaya belajar siswanya dan dalam mengolah media pembelajaran yang efektif mengakibatkan permasalahan ketidak-optimalan siswa dalam menangkap atau memahami pelajaran. Kegagalan siswa dalam menyerap materi pelajaran selain dikarenakan kurang efektifnya metode pengajaran guru, juga bisa dikarenakan siswa yang kurang termotivasi dalam mengikuti materi pelajaran yang membosankan. Contoh kasus materi yang membosankan adalah ketika siswa-siswa dari jurusan musik SMK Kesenian belajar tentang materi matematika namun materi matematika itu tidak dihubungkan dengan bidang keahlian yang akan mereka capai seperti bermusik tersebut, maka siswa jurusan musik tersebut akan menganggap pelajaran matematika sebagai pelajaran yang tidak berguna dan membosankan. Tujuan dari penulisan paper ini adalah untuk mengusulkan metode pembelajaran yang tepat dan menyenangkan bagi Siswa Berbakat Musik yang dominan menggunakan otak kanan. Metode yang digunakan adalah analisis penelitianpenelitian terdahulu dan teori besar pendidikan matematika yang telah teruji. Secara garis besar paper ini mengusulkan metode Joyful Learning yang sesuai dengan kebiasaan siswa yang dominan Otak Kanan agar mampu memotivasi Siswa Berbakat Musik mempelajari matematika.
\end{abstract}

Kata kunci: Pembelajaran, Matematika, Joyful Learning, Musik, Otak Kanan.

Kita menjadi lebih familiar dengan otak kanan ketika Dr. Roger Sperry, dari California Institute of Technology mendapatkan hadiah Nobel tahun 1981 berkat penelitiannya tentang otak kanan saat ini masih kurang dari satu rentang generasi (di tahun 1993). Sampai pekerjaan Dr. Sperry diakui, sebelumnya banyak orang percaya kalau tidak ada perbedaan nyata antara fungsi otak kanan dan otak kiri. (Shicida 1993, hlm.27) 
Robert L. Solso (1995) mengatakan: sebagaimana telah kami singgung sebelumnya, seandainya anda menyingkirkan cranium (tempurung kepala) seseorang, anda akan menjumpai otak yang terdiri dua bagian utama yang tampak jelas. Setiap bagian berukuran sebesar kepalan tangan orang dewasa, dan dikenal sebagai hemisfer kiri dan kanan dari serebral korteks. Meskipun kedua hemisfer tersebut tampak identik, sesungguhnya kedia bagian korteks tersebut memiliki fungsi yang berbeda jauh. Perbedaan fungsi dari kedua belahan otak manusia telah diketahui selama berabad-abad, dan juga telah diamati pada sebagian besar mamalia dan pada berbagai vertebrata.

Rujukan tertulis yang paling awal tentang otak ditemukan pada suatu hieroglif mesir yang tertulis pada abad $7 \mathrm{SM}$. Alphabet hieroglif untuk otak ditunjukkan di sini. Seorang ahli sejarah mesir kuno yang termasyhur, James Breasted menyatakan bahwa alphabet yang menyatakan otak tersebut ditemukan delapan kali dalam naskah-naskah kuno. Dalam sebuah sumber, yang dikenal sebagai: The Edwin Smith Surgeical Papyrus: yang ditemukan di ruang penyimpanan buku-buku langka di New York Academy of Medicine, sang penulis papyrus mendeskripsikan symptomsymptom, diagnosis, dan prognosis (kemungkinan kesembuhan) dari dua pasien yang mengalami cedera di kepala. Orang-orang mesir kuno telah mengetahui bahwa cedera pada suatu sisi otak menyebabkan gangguan pada sisi tubuh yang berlawanan.

Sejarah tentang otak kanan telah diketahui sejak zaman mesir kuno (700 SM) dan diteliti secara ilmiah oleh Roger Spery pada tahun 1950-an dari Institut Teknologi California dengan cara melibatkan pemotongan korpus kolosum pada hewan dan menganalisis akibatnya. Penelitian ini disebut sebagai prosedur belah-otak. Sasaran utama penelitian ini adalah menentukan fungsi-fungsi berbeda yang terasosiasi dengan setiap hemisfer. Bukti lain adanya kecenderungan manusia untuk dominan menggunakan salah satu belahan otak terdapat pada asumsi-asumsi berikut ini: a. Ada orang-orang yang dominan menggunakan tangan kiri/kaki kiri (kidal), ada pula yang dominan menggunakan tangan kanan/kaki kanan; b. Ada orang-orang yang cenderung peka terhadap hal-hal seputar perasaan manusia, namun ada pula orangorang yang kurang peka terhadap perasaan manusia namun lebih peka pada hal-hal seputar rasionalitas (benar-salah)

Bagaimana jika ternyata asumsi-asumsi itu terhubung dengan mekanisme kerja dan spesialisasi fungsi dari masing-masing belahan otak manusia?

Solso (1995) mengatakan "Otak kiri mengontrol gerakan tubuh bagian kanan dan otak kanan mengontrol gerakan tubuh bagian kiri. Otak kiri bertanggung jawab terhadap kemampuan verbal dan matematis, seperti: berbicara, membaca, menulis, 
dan berhitung. Otak kanan berurusan dengan irama, musik, imajinasi, emosi, warna, gambar, dan diagram. Proses berpikir otak kiri bersifat logis, sekuensial, linear, dan rasional (systematic \& detail view), sedangkan belahan otak kanan proses berpikirnya bersifat acak, tidak teratur, intuitif, dan holistic (big picture view)."

Siswa jurusan seni musik terutama yang bakat musiknya tinggi sering menggunakan otak belahan kanan untuk memahami materi pelajaran-pelajaran di bidang seni musiknya, dikarenakan untuk menciptakan sebuah musik yang indah untuk didengar perlu adanya kepekaan emosional dalam kandungan musik tersebut. Sedangkan bagi sebagian siswa Indonesia, matematika adalah pelajaran yang sulit dan membosankan. Entah karena kurikulum pengajaran nasional Indonesia jauh lebih memakai metode pengajaran untuk otak kiri sehingga siswa otak kanan merasa kesulitan atau dikarenakan hal lainnya. Siswa yang dominan otak kanan diperkirakan lemah dalam pelajaran Matematika sejak kecil, sehingga menimbulkan kesulitan dalam menyelesaikan permasalahan matematika, yang kemungkinan cukup bisa menyumbang konsep diri matematik.

Dengan menimbulkan minat belajar dengan cara "Joyful Learning" pada pelajaran matematika dapat mengatasi beberapa masalah belajar siswa dominan otak kanan yang tidak termotivasi mengikuti pelajaran. Kurang optimalnya siswa memahami materi pelajaran matematika bisa jadi dikarenakan kurang efektifnya metode pengajaran guru yang tidak sesuai dengan kondisi siswa dominan otak kanan. Tidak optimalnya siswa memahami materi pelajaran matematika juga bisa jadi dikarenakan siswa kurang termotivasi dengan materi pelajaran matematika yang membosankan. Terkadang guru kurang memahami gaya belajar masing-masing siswanya, penyesuaian materi ajar dengan gaya belajar siswa cukup efektif untuk kesuksesan proses belajar siswa di kelas dan di luar kelas.

\section{Tujuan}

Tujuan dari penulisan Paper Gagasan Pemikiran ini adalah mengusulkan metode pembelajaran Matematika yang tepat untuk Otak Kanan pada Siswa Musik, dengan tahapan:

1. Memaparkan ciri-ciri siswa yang dominan otak kanan

2. Menjelaskan pemahaman karakteristik siswa yang dominan otak kanan dan dampaknya pada proses pembelajaran

3. Menjelaskan gaya belajar siswa secara umum

4. Menjelaskan metode pembelajaran yang menyenangkan diterapkan pada siswa dominan otak kanan

5. Menjelaskan proses kecerdasan manusia secara umum 


\section{Perumusan Masalah}

1. Bagaimana karakteristik siswa yang dominan otak kanan?

2. Bagaimana Gaya Belajar siswa secara umum?

3. Bagaimana Metode Pembelajaran untuk Matematika yang tepat bagi siswa otak kanan?

4. Bagaimana proses pembelajaran yang menyenangkan diterapkan pada siswa dominan otak kanan?

5. Bagaimana proses kecerdasan manusia terbentuk secara umum?

\section{PEMBAHASAN}

\section{Siswa yang dominan otak kanan}

Shichida (1993) mengatakan "Otak terbagi menjadi hemisfer kiri dan kanan, yang masing-masing memiliki fungsi yang berbeda. Dengan kata lain, kedua "komputer" yang berbeda secara sadar dan lambat, dan komputer otak kiri mempunyai kemampuan "proses sadar kecepatan rendah". Otak kanan bekerja otomatis pada kecepatan tinggi melebihi kesadaran individu, dan komputer dalam otak kanan mempunyai kemampuan "proses otomatis kecepatan-tinggi"." (hlm.85)

Solso (1995) mengatakan "Otak manusia terdiri atas dua belahan otak, yaitu belahan otak kiri dan belahan otak kanan. Kedua belahan otak tersebut memiliki fungsi dan peran yang berbeda, tetapi kedua belahan otak tersebut saling melengkapi satu sama lain. Otak kiri mengontrol gerakan tubuh bagian kanan dan otak kanan mengontrol gerakan tubuh bagian kiri. Otak kiri bertanggung jawab terhadap kemampuan verbal dan matematis, seperti: berbicara, membaca, menulis, dan berhitung. Otak kanan berurusan dengan irama, musik, imajinasi, emosi, warna, gambar, dan diagram. Proses berpikir otak kiri bersifat logis, sekuensial, linear, dan rasional, sedangkan belahan otak kanan proses berpikirnya bersifat acak, tidak teratur, intuitif, dan holistik. Dalam kehidupan sehari-hari, otak kanan dan otak kiri secara alami saling bekerja sama. Kedua belahan otak ini mempunyai peran yang sama pentingnya".

Lebih lanjut Menurut Rebecca Treays (dalam Wasi Dewanto, 2004) mengatakan bahwa "otak kiri digunakan untuk berbicara dan berbahasa, menyelesaikan tugas-tugas yang membutuhkan urutan tertentu seperti melakukan penjumlahan, mengikat tali sepatu. Sedangkan otak kanan digunakan untuk berimajinasi dalam gambar. Pada umumnya setiap orang biasanya memiliki kecenderungan untuk dominan pada salah satu belahan otak tersebut. Ada yang dominan otak kiri, ada yang dominan otak kanan. Dominasi peran belahan otak 
dapat terjadi karena dipengaruhi oleh lingkungan yang melingkupi orang tersebut, misalnya: sistem pendidikan di keluarga, di sekolah, dan di masyarakat. Kondisi yang merugikan adalah apabila dominasi itu menyebabkan fungsi belahan otak lainnya menjadi lemah. Kalau hal ini terjadi, maka akan membuat kemampuan berpikir kita menjadi tidak optimal".

\section{A. Ciri-ciri siswa yang dominan otak kanan}

Dari beberapa teori di atas dapat kita simpulan ciri-cirinya adalah:

1. Berfikir acak (random)

2. Tidak teratur, tidak suka sistematika yang terlalu rigit

3. Intuitif, menebak jawaban langsung (inti)

4. Holistik (Big Picture)

5. Proses otomatis kecepatan tinggi (bawah sadar menyerap secara langsung info)

6. Peka terhadap hal-hal bersifat emosional (keindahan \& perasaan manusia lain)

B. Karakteristik siswa yang dominan otak kanan

Dalam kemampuan khusus berhitung otak kanan Shichida (1993) mengatakan: sampai saat ini (1993) banyak orang percaya kalau berhitung merupakan fungsi otak kiri. Namun otak kanan memiliki kemampuan berhitung istimewa yang berbeda dari otak kiri. Fungsi ini sering dikaitkan sebagai kemampuan berhitung "secepat kilat' dan biasanya dikuasai oleh individu yang disebut Savant. Sebagai contoh, di awal abad ke-20, ada seorang pria yang terbelakang dan buta bernama Flure. la menghabiskan seluruh hidupnya di rumah sakit perancis. Dari bayi, ia sudah menunjukkan bakat luar biasa di mental aritmetika. Mendengar kabar burung mengenai kemampuannya yang mengagumkan, sebanyak 12 orang ahli matematika Eropa berkumpul untuk menguji kemampuan Flure.

Para ahli matematika mengujinya dengan hati-hati. Di salah satu pengujiannya, mereka bertanya pada Flure, "Ada 64 kotak. jika kamu menaruh satu biji jagung di dalam kotak pertama, dua biji di kotak kedua, dan selanjutnya melipatgandakan jumlah biji tersebut di kotak-kotak berikutnya, berapa banyak biji yang akan ada di kotak ke-64? ini merupakan soal geometri, dan bisa ditampilkan dengan rumus berikut: $1+2+22+23+$ 263

Jika anda tahu rumusnya, maka soal ini bisa diselesaikan dengan menghitung "264-1"; tapi menghitung di luar kepala "264" sangatlah sulit. Namun Flure, kurang dari 30 detik, mampu memberikan sebuah jawaban benar: 18.446.734.073.709.555.615. Para ilmuwan terpana akan bakat Flure, dan tak bisa menjelaskannya. Kemampuan Flure melebihi penjelasan ilmiah saat ini (1993). 
Contoh lain kemampuan berhitung secepat kilat Savant juga dilaporkan seorang psikiater Amerika, Darold A. Treffert dalam bukunya Extraordinary People: Understanding Savant Syndrome di tahun 1989. (hlm. 1-2)

Lebih lanjut dalam bagian bukunya "Sains membuktikan Kemampuan berhitung Otak Kanan" Makoto Shichida (1993) mengatakan:

Nona Yuka Hatano, 24 tahun, dari kota Maizuru, Kyoto, meraih juara utama berhitung sempoa, memenangkan empat penghargaan tertinggi pertandingan sempoa: "All Japan Abacus Calculation Championship Series", "National Abacus Calculation Contest", "Abacus Calculation Master Tournament", dan "World's Greatest Calculation Skill Tournament". la juga bisa menghitung luar kepala soal 16 digit angka, yang lebih cepat daripada kalkulator. Bahkan ia telah mematahkan anggapan umum yang mengatakan mental aritmatika hanya terbatas pada 13 digit. Hatano mengatakan, "kapan pun saya melihat atau mendengar bilangan angka, sebuah sempoa muncul di kepala saya. Biji-biji sempoa tersebut bergerak sendiri, dan jawabannya pun muncul seketika."

Teknik aritmatika wanita ini umumnya juga dimiliki oleh juara berhitung sempoa lainnya. Sebagai contoh, Tuan Kazusuke Kanemoto, seorang mahasiswa di Universitas Ritsumeikan dan juara sempoa Jepang tahun 1985, mengatakan bahwa, ketika ia melihat bilangan, mereka langsung menjadi imaji (citra). Sebagai contoh, ketika ia melihat angka "253", angka-angka tersebut secara otomatis muncul di kepalanya sebagai batang sempoa dengan panjang 2,5,3. Profesor Yoshiya dari Nippon Medical College pernah melakukan pemindaian Positron Emission Tomography (PET) (PET: digunakan untuk memindai penggunaan glukosa di dalam otak) untuk mempelajari mekanisme otak Nona Hatano, juara umum lomba sempoa, menghitung dengan mental aritmetika secara lisan. la menjelaskan hasil dari penelitiannya dengan mengatakan, "orang biasanya menggunakan otak kirinya untuk mental aritmetika. namun selama Nona Hatano berhitung, ternyata bagian belakang otak kanannya, yang mengatur fungsi visual yang digunakan. Hasil yang sama teridentifikasi pada master mental aritmetika lain yang juga diuji." Hasil ini mendukung anggapan bahwa di otak kanan, fungsi berhitung yang berbeda telah diaktifkan.

Menurut kesimpulan penulis dari teori yang dibaca oleh penulis, karakteristik siswa dominan otak kanan adalah:

1. Suka gambar/visualisasi untuk merangsang imajinasi

2. Tidak mampu mengikuti prosedural yang terlalu sistematis (Randomized)

3. Menghubungkan kejadian kecil-kejadian kecil kepada peristiwa yang lebih besar (Pandangan Holistik). 


\section{Perilaku Siswa Dominan Otak Kanan pada proses pembelajaran}

Sousa (2009) dalam pembahasan Belahan Otak (Cerebral Hemispheres) mengatakan: sejak karya Roger Sperry pada tahun 1960-an, ilmuwan neurosains telah menerima pemikiran bahwa dua belahan otak tidak saling menjadi citra cermin. Kedua belahan itu berbeda secara structural, biokimia, dan fungsional (Sousa, 2006). Contoh, dalam sebagian besar orang, lobus frontal kanan lebih menonjol keluar dan lebih lebar daripada lobus frontal kiri. Lobus oksipital kiri (di bagian belakang otak) lebih menonjol keluar dan lebih lebar daripada lobus oksipital kanan. Neurotransmitter (substansi penyampai rangsangan neuron melintasi sinapsis) norepinefrin lebih dominan di belahan otak kanan, sementara dopamine lebih dominan di belahan otak kiri. Reseptor estrogen lebih dominan di belahan otak kanan daripada belahan otak kiri.

Otak belahan kiri memantau bidang ucapan. Otak kiri memahami interpretasi kata secara harfiah, dan mengenali kata, huruf, serta angka yang tertulis sebagai kata-kata. Ini bersifat analitis, mengevaluasi materi nyata dalam cara rasional. Otak kanan megumpulkan informasi lebih dari gambar dibandingkan kata-kata, dan mcari pola. Otak kanan menginterpretasikan bahasa lewat konteks, yaitu bahasa tubuh, isi yang emosional, dan nada suara, bukan lewat makna harfiah. Belahan otak kana berfokus pada operso hubungan matematika, seperti geometrid an trigonometri. (Gazzaniga, Ivr, dan Mangun, 2002)

Menurut kesimpulan penulis dari teori-teori yang dibaca, karakteristik prilaku siswa dominan otak kanan dalam pembelajaran adalah:

1. Menginginkan materi pelajaran disertasi ilustrasi visual (gambar-gambar)

2. Berikan tahapan inti atau urutan umum saja, tanpa terlalu detail

3. Menghubungkan materi-materi pelajaran di kelas terhadap kehidupan umum sehari-hari.

\section{Kondisi Psikologis Siswa Remaja}

\section{Perkembangan Kognitif Remaja:}

Kesatuan perilaku yang sama yang dijumpai sebelumnya dalam beragam tahapan ditemukan lagi antara usia 11-12 tahun dan 14-15 tahun, ketika subjek berhasil membebaskan dirinya dari yang konkret dan dalam menemukan realitas di dalam suatu kelompok kemungkinan transformasi. Peminggiran fundamental akhir ini, yang terjadi di akhir masa kanak-kanak, bersiap untuk memasuki masa remaja, yang karakteristik pokoknya adalah pembebasan yang serupa dari yang konkret menuju pada kecenderungan ketertarikan yang berorientasi kea rah non-masa kini 
dan masa depan. Masa kini adalah masa bagi ideal-ideal besar dan permulaan teoriteori, serta waktu adaptasi masa sekarang dengan realitas. (Piaget 1969, hlm. 151)

Ditinjau dari perspektif teori kognitif Jean Piaget, maka pemikiran masa remaja telah mencapai tahap pemikiran operasional formal, yakni suatu tahap perkembangan kognitif yang dimulai usia kira-kira 11 atau 12 tahun dan terus berlanjut sampai remaja mencapai masa tenang atau dewasa (Lerner \& Hustlsch, 1983). Pada tahap ini anak sudah dapat berpikir secara abstrak dan hipotetis. Pada masa ini, anak sudah mampu memikirkan sesuatu yang akan atau mungkin terjadi, sesuatu yang abstrak. (Desmita 2005, hlm. 195)

Perkembangan aspek kognitif pada remaja dalam Desmita (2005):

\section{Perkembangan Pengambilan Keputusan}

Dalam hal pengambilan keputusan ini, remaja yang lebih tua ternyata lebih kompeten daripada remaja yang lebih muda, sekaligus lebih kompeten dibandingkan anak-anak. Dibandingkan dengan anak-anak, remaja yang lebih muda cenderung menghasilkan pilihan-pilihan, menguji situasi dari berbagai perspektif, mengantisipasi akibat dari keputusan - keputusan, dan mempertimbangkan kredibilitas sumbersumber.

Meskipun demikian, keteranpilan pengambilan keputusan oleh remaja yang lebih tua seringkali jauh dari sempurna, dan kemampuan untuk mengambil keputusan tidak menjamin bahwa keputusan semacam itu akan dibuat dalam kehidupan sehari-hari, dimana luasnya pengalaman sering memainkan peran yang sangat penting. Untuk itu, remaja perlu memiliki lebih banyak peluang untuk mempraktekkan dan mendiskusikan pengambilan keputusan yang realistis.

\section{Perkembangan Orientasi Masa Depan}

Remaja mulai memberikan perhatian yang besar terhadap berbagai lapangan kehidupan yang akan dijalaninya sebagai manusia dewasa di masa mendatang. Di antara lapangan kehidupan di masa depan yang banyak mendapat perhatian remaja adalah lapangan pendidikan (Nurmi, 1989), di samping dunia kerja (dunia karir) dan hidup berumah tangga (Havighurst, 1984). Menurut G. Trosmmsdorf (1983), orientasi masa depan merupakan fenomena kognitif motivasional yang kompleks, yakni antisipasi dan evaluasi tentang diri di masa depan dalam interaksinya dengan lingkungan. Sedangkan menurut Nurmi (1991), orientasi masa depan berkaitan erat dengan harapan, tujuan, standar, rencana, dan strategi pencapaian tujuan di masa yang akan datang.

3. Perkembangan Kognisi Sosial

Menurut Dacey \& Kenny (1997), yang dimaksud dengan kognisi sosial adalah kemampuan untuk berpikir secara kritis mengenai isu-isu dalam hubungan 
interpersonal, yang berkembang sejalan dengan usia dan pengalaman, serta berguna untuk memahami orang lain dan menentukan bagaimana melakukan interaksi dengan mereka.

Salah satu bagian penting dari perubahan perkembangan aspek kognisi sosial remaja ini adalah apa yang diistilahkan oleh psikolog David Elkind dengan egosentrisme yakni kecenderungan remaja untuk menerima dunia (dan dirinya sendiri) dari perspektifnya mereka sendiri. Dalam hal ini, remaja mulai mengembangkan suatu gaya pemikiran egosentris, dimana mereka lebih memikirkan tentang dirinya sendiri dan seolah-olah memandang dirinya dari atas.

\section{Gaya belajar siswa}

Keefe (1979) memandang gaya belajar sebagai "cara seseorang dalam menerima, berinteraksi, dan memandang lingkungannya". Selanjutnya Keefe (1991) menggambarkan bahwa "gaya belajar yang baik akan menunjukkan karakteristik seorang pembelajar dan strategi instruksional pembelajar tersebut. Sebagai seorang pelajar karakteristik, gaya belajar merupakan indikator bagaimana para pelajar belajar dan suka belajar. Sebagai strategi pembelajaran, itu menginformasikan kognisi, konteks dan isi pembelajaran". Drummond (1998) mendefinisikan gaya belajar sebagai "an individual's preferred mode and desired contition of learning." "Maksudnya, gaya belajar dianggap sebagai cara belajar atau kebiasaan belajar yang disukai oleh pembelajar". (hlm.186). Willing (1998) mendefinisikan gaya belajar sebagai "kebiasaan belajar yang disenangi oleh pembelajar".

Sims \& Sims (1995), menyatakan bahwa "bagaimana seseorang belajar merupakan konsep fokus dari gaya belajar. Gaya belajar dapat didefinisikan sebagai karakteristik kognitif, afektif, dan perilaku-perilaku psikologis yang berlaku sebagai indikator bahwa pembelajar relatif stabil dalam merasakan adanya interaksi dengan/dan merespon terhadap lingkungan belajar". Messick (1996) mengusulkan bahwa "gaya kognitif individu bervariasi dan terkait dengan perbedaan individu". Menurut Marsha (1996) menyatakan "gaya belajar merupakan hal yang penting karena pendidikan disesuaikan dengan keunikan individu. Perbedaan individu harus dihargai karena gaya belajar merupakan ungkapan dari keunikan setiap orang. Dengan individu, merupakan bentuk nyata identitas seseorang, bersama-sama, gaya belajar juga menyampaikan kesempurnaan budaya kita". Menurut Gunawan (2004) gaya belajar adalah "cara yang lebih kita sukai dalam melakukan kegiatan berpikir, memproses dan mengerti suatu informasi. Misalnya jika kita ingin mempelajari mengenai tanaman, apakah kita lebih suka nonton video soal tanaman,

\footnotetext{
Seminar Nasional Psikologi "Aktualisasi Potensi Anak Bangsa Menuju Indonesia Emas"
} 
mendengarkan ceramah, membaca buku ataukah kita bekerja langsung di perkebunan atau mengunjungi kebun raya."

Menurut De Porter (2001) menyatakan bahwa "gaya belajar seorang anak adalah kombinasi bagaimana anak tersebut menyerap, kemudian mengatur dan mengolah informasi”. Mortimore (2008) dalam bukunya Dyslexia and Learning Style menyatakan bahwa "gaya belajar merupakan satu aspek dari gaya kognitif, hal ini menandakan bahwa adanya perbedaan antara gaya belajar dengan gaya kognitif. Perbedaan-perbedaan ini penting karena gaya kognitif secara otomatis dilakukan seseorang dalam memproses stimulasi yang datang dan gaya belajar dapat dilihat dalam hal strategi bagaimana seorang siswa mengatasi tugas-tugas dan situasi belajar".

De Porter (2001) menyatakan bahwa Gaya belajar siswa dapat dibedakan menjadi 3 yaitu:

1. Visual adalah gaya belajar yang lebih mendominasi pada penglihatan,

2. Auditorial adalah gaya belajar siswa yang lebih menerima pelajaran dengan pendengaran yang lebih dominan,

3. Kinestetik adalah gaya belajar siswa yang lebih menerima pelajaran yang dilakukan dengan gerakan, bekerja dan menyentuh.

Beberapa gaya belajar juga sudah didokumentasikan. Witkin (1949) menggunakan istilah filed independent dan field-dependent. Gregorc (1982) menggunakan istilah "Kolb (1976) menggunakan istilah Converger, Diverger, Assimilator, dan Accomodator. Selanjutnya Istilah gaya belajar menurut Kolb inilah yang akan penulis gunakan dalam penelitian ini. Menurut David Kolb (1984) kecenderungan atau orientasi seseorang dalam proses belajarnya dipengaruhi empat model belajar yaitu feeling, thingking, wacthing dan doing.

\section{Metode pembelajaran yang menyenangkan (Joyful Learning)}

Kosasih (2010) mengemukakan "pembelajaran yang menyenangkan dalam pelaksanaannya perlu memperhatikan hal-hal berikut: memahami sifat yang dimiliki siswa, mengenal siswa secara perorangan, menguasai substansi ilmu, metodologi dan teknologi, memiliki sikap nilai dan kebiasaan berpikir produktif, memutahirkan ilmu pengetahuan, keterampilan dan sikap". Rusman (2011) menyatakan "joyful learning adalah adanya pola hubungan yang baik antara guru dengan siswa dalam proses pembelajaran". (hlm.326)

Suasana pembelajaran perlu diperhatikan dengan baik oleh guru, sebab menciptakan suasana yang menyenangkan dan jauh dari rasa tertekan dapat membangkitkan motivasi siswa. Untuk merealisasikan hal tersebut guru harus 
bertindak kreatif dengan merancang kegiatan yang dapat membuat siswa tertarik untuk berinteraksi dalam pembelajaran sehingga tidak akan muncul kebosanan dalam diri siswa. Maka dari itu dalam pendekatan joyful learning media berperan sangat penting agar tercipta kesenangan dan interkasi pada diri siswa. Perlu diperhatikan bahwa semakin banyak jenis media yang digunakan akan membuat siswa semakin tertarik dalam mengikuti kegiatan pembelajaran.

Menurut Asyhar (2012) menyatakan bahwa "media memiliki peranan yang sangat penting, yaitu suatu sarana atau perangkat yang berfungsi sebagai perantara atau saluran dalam suatu proses komunikasi antara komunikator dan komunikan. Media merupakan salah satu komponen yang sangat penting dalam pembelajaran dan dapat dipandang sebagai salah satu alternatif strategi yang efektif dalam membantu pencapaian tujuan pembelajaran. Pentingnya peran media dalam pembelajaran mengharuskan guru untuk lebih kreatif dan inovatif dalam memanfaatkan berbagai sumber belajar dan media". (hlm.5)

Dalam hal pembelajaran dengan manajemen Otak, Wiindura (2008) Mengatakan:

Brain management atau Manajemen Otak adalah kegiatan memahami dan meningkatkan kemampuan otak untuk selalu dapat mengupgrade potensi dan kapasitas setiap saat. Dengan kata lain yang lebih sederhana, manajemen otak adalah upaya kita meningkatkan Hardware atau otak kita, bukan pada software atau ilmu-ilmu semata. Otak kita secara mental terbagi atas dua belahan atau hemisfer, yaitu hemisfer kiri dan hemisfer kanan. Masing-masing hemisfer ini mempunyai fungsi yang berbeda dan sifat yang bertolak belakang. Berikut perbedaan karakteristik kedua belahan otak tersebut.

Hal-hal yang berhubungan dengan aktivitas berbahasa, seperti menulis, membaca, berbicara, dan mendengarkan dilakukan dengan menggunakan otak kiri. Saat kita menghitung, seperti menggunakan logika untuk memecahkan masalah, kita juga menggunakan otak kiri. Sifat memori otak kiri adalah jangka pendek. Sebaliknya, saat menyusun balok-balok lego, kita menggunakan otak kanan. Saat kita diminta menceritakan kembali isi suatu buku dalam waktu beberapa menit, berarti daya konseptual kita sedang bekerja, ini berarti kita sedang menggunakan otak kanan. Begitu juga saat kita menikmati pemandangan alam, lukisan dan musik. Sifat memori otak kanan adalah jangka panjang.

Berikut ada beberapa alternatif yang dapat digunakan dan dikembangkan oleh guru matematika dalam pembelajaran matematika yang melibatkan otak kiri dan otak kanan atau dikenal dengan manajemen otak (Brain Management):

1. Gunakan warna.

\footnotetext{
Seminar Nasional Psikologi "Aktualisasi Potensi Anak Bangsa Menuju Indonesia Emas"
} 
Warna-warni merupakan aktif otak kanan. Oleh karena itu, guru matematika dalam pembelajarannya dapat menggunakan kapur/spidol warna-warni untuk menjelaskan bagian-bagian yang penting. Apalagi dapam dalam menggambar bentuk-bentuk geometri baik bidang maupun ruang. Dengan menggunakan warna, berarti otak kiri akan aktif, yaitu berkaitan dengan materi matematikanya, sedangkan otak kanan akan aktif, tak kalah melihat gambar-gambar yang berwarna. Pada buku catatan atau cetak siswa juga diberikan kesempatan untuk memberikan warna denga stabilo pada bagian yang menurutnya penting.

2. Gunakan alat peraga.

Pelajaran matematika agar mudah dipahami dapat menggunakan alat peraga terutama pada tingkat pendidikan dasar. Dengan menggunakan alat peraga siswa dapat melakukan visualisasi dan lebih memahami materi matematika, terutama pada topik geometri. Alat peraga yang digunakan sebaniknya yang dapat dimanipulasi oleh siswa, sehingga secara fisik dan mental siswa terlibat dalam belajar. Dengan alat peraga ini, berarti keduabelahan otak anak akan aktif dan pelajaran matematika tidak membosankan, tetapi menyenangkan.

3. Imajinasi.

Kemampuan imajinasi atau khayal sebaik dapat dibangkaikan saat belajar matematika. Imajinasi akan mengaktifkan otak kanan. Misalnya, saat guru menerangkan tentang lingkaran, siswa diminta membayangkan lingkaran tersebut. Proses membayangkan lingkaran dapat diikuti dengan menggambar lingkaran dengan jari tangan. Begitu juga, apabila membahas soal-soal cerita/memecahkan masalah, siswa dibawa untuk membayangkan kondisi yang sebenarnya.

4. Memberikan kesempatan anak untuk mengeluarkan pendapat.

Apabila anak dapat mengemukakan pendapatnya, ini berarti anak telah mampu memahami konsep. Mengemukakan secara konseptual merupakan aktifnya otak kanan, sedang proses diskusi dan membaca adalah aktifnya otak kiri. Jadi, dalam pembelajaran tersebut telah melibatkan otak kiri dan otak kanan. Untuk dapat mengembangkan pembelajaran matematika yang memungkinkan anak dapat mengemukakan pendapatnya diperlukan pendekatan pembelajaran tertentu.

Salah satu pendekatan pembelajaran yang dapat digunakan oleh guru adalah pendekatan pembelajaran matematika realistik (Realistic Mathematics Education). Hal ini dikarenakan pendekatan Pembelajaran Matematika Realistik (PMR) mempunyai prinsif dan karakteristik yang mengharuskan siswa terlibat dalam proses penemuan konsep. Adapun prinsip dan karakteristik PMR menurut Gravemeijer (1994), yaitu sebagai berikut: 
prinsip PMR adalah: (a) Guided Reinvention and Progressive Mathematization (Penemuan terbimbing dan Bermatematika secara Progressif, (b) Didactical Phenomenology (Penomena Pembelajaran), (c) Self-developed Models (Pengembangan Model Mandiri),

dan karateristik PMR adalah: (a) menggunakan masalah kontekstual; (b) menggunakan model; (c) menggunakan kontribusi dan produksi siswa; (d) interaktif; (e) keterkaitan.

\section{Research Evidences}

\section{a. Penelitian-penelitian tentang Otak (dan teori Kecerdasan)}

\section{Howard Gardner}

Teori Kecerdasan Mulipel (MI/Multipel Intelligence) telah digunakan di sistem sekolah di seluruh belahan dunia, untuk mempromosikan segala jenis perubahan pengajaran dan kurikulum. Sejumlah program pelajaran hampir secara eksklusif berbasis pada MI. Di dalam karyanya, Gardner (1983) telah menyatakan, ukuran tradisional untuk mengenali siswa yang sangat cerdas terlalu mengandalkan tes IQ, yang berfokus pada keterampilan linguistik dan logis/matematis. Sebagai akibatnya, sekolah semakin memilih $\mathrm{Ml}$ sebagai cara alternatif untuk mengidentifikasi siswa yang sangat cerdas. Tetapi, masalah dengan pendekatan ini adalah pada penetapan cara untuk mengembangkan isntrumen, yang bisa mengukur setiap kecerdasan dengan reliabilitas dan validitas. (Sousa 2009, hlm. 20)

\section{Robert Stenberg}

The Triarchic Theory: Dua tahun setelah karya Gardner muncul, Robert Stenberg (1985) di Yale mengusulkan teori yang membedakan tiga jenis kecerdasan: analitis, kreatif, dan praktis. Orang-orang dengan kecerdasan analitis (penganalisis) memiliki kemampuan dalam menganalisis, mengkritik, dan mengevaluasi. Mereka yang cerdas kreatif terutama hebat dalam penemuan, penciptaan, dan pembuatan. Sebaliknya, orang yang cerdas secara praktik (praktisi) menguasai penerapan, pemanfaatan, dan penggunaan. (Sousa 2009, hlm 20-21)

Teori Kecerdasan yang Sukses: pada 1997, Sternberg memperkenalkan Teori Kecerdasan yang Sukses (theory of successful intelligence) yang melibatkan penggunaan kecerdasan orang untuk mencapai tujuan hidup yang ditetapkan orang tersebut untuk dirinya sendiri, dalam konteks budaya dan sosial khusus. Orang cerdas yang sukses menggali kekuatan mereka, dan memanfaatkan banyak kekuatannya saat mereka mengenali kelemahannya serta menemukan cara, untuk memperbaiki atau menyeimbangkan kelemahan mereka. Keduanya penting, 
walaupun siswa perlu belajar untuk memperbaiki aspek prestasi mereka yang tidak terlalu baik, mereka juga harus mengenali bahwa mungkin mereka tidak akan pernah bisa hebat di semua jenis tindakan mereka. Adalah cerdas untuk menemukan cara di sekitar kelemahan, seperti mencari bantuan orang lain dan memberikan bantuan sebagai imbalannya. (Sousa 2009, hlm. 22)

Kecerdasan yang Sukses di Kelas. Pengajaran dan tes seharusnya memberikan suatu penggunaan yang seimbang dari komponen triarkis, yaitu pemikiran analitis, kreatif, dan praktik. Di dalam pendekatan ini, guru membantu siswa meningkatkan kekuatan mereka dan mengatasi kelemahan-kelemahan mereka. Tugas kelas dan tes sebagian besar terpusat di sekitar aktivitas yang membutuhkan analisism kreatifitas, dan penerapan. Jenis ini mencapai lebih dari pola kemampuan siswa, sehingga mereka bisa secara intrinsik termotivasi untuk menyukseskan kerja mereka. Sternberg menyatakan, pengajaran untuk Kecerdasan yang Sukses meningkatkan prestasi siswa dengan alasan-alasan sebagai berikut:

- Hal itu mendorong pengkodean memori yang lebih mendalam dan elaboratif daripada pengajaran tradisional, sehingga siswa belajar dan mengingat materi dalam cara yang meningkatkan ingatan di waktu tes.

- Hal itu mendorong bentuk pengkodean materi yang lebih beragam, sehingga ada lebih banyak pola mengingat materi dan kemungkinan yang lebih besar untuk mengingat.

- Hal itu memungkinkan siswa untuk menekan kekuatan dan mengatasi kelemahan.

- Hal itu lebih memotivasi bagi guru dan siswa

Hasil penelitian yang dilakukan oleh Sternberg menunjukkan bahwa siswa yang diajar dan dinilai dengan pendekatan ini, di banyak bidang pelajaran, menunjukkan tes yang lebih baik daripada siswa yang diajar secara konvensional (Sternberg \& Grigorenko, 2004).

\section{b. Penelitian tentang Gaya Belajar Siswa}

Mengingat kenyataan dalam pembelajaran matematika dan kebutuhan dalam kehidupan sehari-hari tersebut, diperlukan pembelajaran yang dapat membekali siswa dalam suatu kemampuan untuk dapat berfikir aktif dan kreatif dalam proses pembelajaran matematika. Proses pembelajaran matematika pada hakekatnya untuk mengembangkan keaktifan siswa melalui berbagai interaksi dan pengalaman belajar. Aktifitas siswa menjadi hal yang penting karena kadangkala guru lebih menekankan pada aspek kognitif, dengan menekankan pada kemampuan mental yang dipelajari 
sehingga hanya berpusat pada pemahaman bahan pengetahuan. Guru perlu menyadari bahwa pada saat mengajar, guru lebih memposisikan dirinya sebagai fasilitator.

Keaktifan siswa dalam belajar merupakan persoalan penting dan mendasar yang harus dipahami, disadari dan dikembangkan oleh setiap guru dalam proses pembelajaran. Keaktifan belajar ditandai oleh adanya keterlibatan secara optimal, baik intelektual, emosi dan fisik. Siswa merupakan manusia belajar yang aktif dan selalu ingin tahu. Daya keaktifan yang dimiliki anak secara kodrati itu akan dapat berkembang ke arah yang positif saat lingkungannya memberikan ruang yang baik untuk perkembangan keaktifan itu (Aunurrahman, 2009: 119).

Hasil penelitian menunjukkan terdapat pengaruh yang signifikan gaya belajar terhadap prestasi belajar matematika, hal ini ditunjukan dengan nilai sig $=0,001<$ 0,05 . Terdapat pengaruh yang signifikan keaktifan terhadap prestasi belajar matematika, hal ini dapat dilihat dari nilai $\mathrm{F}$ hitung $=13,418>\mathrm{F}$ tabel $=3$, 08, dengan $\operatorname{sig}=0,00<\alpha=0,05$. Tidak terdapat pengaruh interaksi metode pembelajaran kooperatif dan gaya belajar terhadap prestasi belajar Matematika.

\section{KESIMPULAN DAN REKOMENDASI}

\section{Kesimpulan}

Karakteristik Siswa yang Dominan Otak Kanan adalah berfikir secara intuitif, tidak suka dengan peraturan yang terlalu detail, dan menyukai visualisasi (gambar \& video) sebagai alat bantu berfikir atau mengabstraksikan sesuatu. Kondisi Psikologis Remaja terhadap Karir mempengaruhi Motivasi Belajar, karena pada fase remaja sudah menghubungkan nilai sesuatu hal yang dipelajarinya untuk kepentingan dia di masa dewasa (karir). Hal ini terwujud dalam: a. keingingan mengembangkan alternative-alternatif Decision Making dalam Problem Solving; b. keinginan menghubungkan materi pelajaran dengan pengembangan pendidikan dan karir di masa depan; c. kondisi egosentrisme remaja lebih mengutamakan tujuan pribadi dalam belajar. Nilai, fungsi, dan manfaat Joyful Learning adalah untuk menumbuhkan minat serta motivasi siswa terhadap pelajaran matematika.

\section{Rekomendasi}

Solusi Substansial (Prinsip Inti)

Menimbulkan minat belajar dengan cara "Joyful Learning" pada pelajaran matematika dapat mengatasi beberapa masalah belajar siswa dominan otak kanan yang tidak termotivasi mengikuti pelajaran. Penyesuaian materi ajar dengan gaya belajar siswa cukup menunjang kesuksesan proses belajar siswa di kelas dan di luar 
kelas. Solusi lainnya dari permasalahan belajar matematika otak kanan adalah menstimulasi penyelesaian masalah matematika dengan peran otak kanan terlebih dahulu, yaitu memperkirakan hitungan secara kasar, menggunakan perbandingan sederhana, dan membayangkan banyak alternatif penyelesaian masalah. Lalu setelah stimulasi awal itu disambungkan dengan peran otak kiri dalam hal detail/ketelitian, sehingga terjadi keseimbangan peran antara otak kanan dan otak kiri. Dengan adanya usaha peningkatan kemampuan problem solving dan kemampuan menyediakan alternatif-alterfnatif kemungkinan jawaban pada persoalan matematik juga diharapkan dapat meningkatkan kepercayaan diri.

Otak kanan manusia bekerja dalam memperhitungkan matematis secara perkiraan kasar, dan perbandingan umum. Sedangkan otak kiri adalah perhitungan matematis yang sistematis, procedural, dan detail. Jadi otak kanan harus dilatih untuk menggunakan berbagai rumus yang ia bisa. Target akhirnya bukan ikut menghafal sebuah rumus yang diajarkan guru dan mengulang rumus tersebut pada satu soal, tetapi biarkan siswa otak kanan untuk menyelesaikan masalah dengan caranya sendiri dan guru hanya bertugas sebagai pembimbing atau pengawas yang member solusi jika dia bertanya. Dengan membiarkan siswa otak kanan menggunakan rumusnya sendiri akan menimbulkan kepercayaan diri.

Solusi Proses Pembelajaran Matematika Bagi Siswa Jurusan Musik:

a. Menjelaskan nilai filosofis dasar hadirnya pelajaran matematika untuk kehidupan sehari-hari, lalu menghubungkan materi pelajaran matematika dengan permasalahan di bidang musik, lalu menjelaskan manfaat melatih menyelesaikan permasalahan matematika untuk pengembangan karir mereka di masa depan, karena tidak semua siswa jurusan musik ketika lulus akan selalu menjadi seniman musik, bisa jadi manajer artist, ataupun menjadi Sarjana dalam Bidang lain seperti Bidang Komputer misalnya. Begitupun pemrogaman musik di sebuah software dalam komputer pula memerlukan perhitungan matematis.

b. Penjelasan definisi filosofis suatu bab pelajaran matematika agar siswa faham maksud hadirnya materi pelajaran tersebut. Contoh: Pelajaran Trigonometri, dijelaskan dalam definisi "Tri”, "Gono", dan "Metri”, dimana Tri artinya Tiga, Gono artinya Sudut, dan Metri artinya pengukuran. Jadi Trigonometri adalah pengukuran Tiga Sudut (dalam sebuah bentuk segitiga). Agar siswa memahami secara berkesan apa arti Trigonometri.

c. Memilih media \& materi yang tepat dengan gaya belajar: media untuk gaya belajar visual, media untuk gaya belajar auditoris, media pembelajaran gaya belajar kinestetis. 
d. Menghidupkan suasana diskusi alternatif-alternatif penyelesaian satu masalah matematika dengan belajar dalam kelompok-kelompok kecil dengan satu orang siswa unggul dalam matematika sebagai konselor sebaya. 


\section{DAFTAR PUSTAKA}

Asma, Nur. 2006 Model Pembelajaran Kooperatif. Jakarta: Depdiknas Dirjen Dikti Direktorat Ketenagaan.

De Porter, Bobbi \& Hernacki, Mike. 2000. Quantum Learning (Membiasakan Belajar Nyaman dan Menyenangkan. Terjemahan Bandung: Kaifa.

De Porter, Bobby dkk. 2009. Quantum Teaching. Bandung: Kaifa.

Desmita. 2005. Psikologi Perkembangan. Bandung: PT. Remaja Rosda karya.

Gunawan, Adi W. 2003. Genius Learning Strategy: Petunjuk Praktis Untuk Menerapkan Accelerated Learning. Jakarta: Gramedia Pustaka Utama.

Gredler, Margaret E. Bell. 1991. Terjemahan: Belajar dan Membelajarkan. Jakarta: CV. Rajawali.

Kosasih, Andreas. $2011 . \quad$ Joyful Learning. Tersedia pada http://www.ikawinamadiun.com/news2.php?op=7 (diakses tanggal 7 januari 2013).

Piaget, Jean. 1969. The Psychology of Child (Terj. Miftahul Jannah: Psikologi Anak, 2010). Yogyakarta: Pustaka Pelajar.

Pitadjeng. 2006. Pembelajaran Matematika Yang Menyenangkan. Jakarta: Depdiknas dirjen dikti.

Rusman. 2011. Model-Model Pembelajaran. Jakarta: PT Rajagrafindo Persada.

Sanjaya, Wina. Strategi Pembelajaran: Berorientasi Standar Proses Pendidikan. Jakarta: Kencana Prenada Media Group, 2008.

Santoeso, Sugeng, 2000. Problematika Pendidikan dan Cara Pemecahannya. Jakarta: Kreasi Pena Gading.

Santrock, John W. 2007. Educational Psychology (Ed. Ke-2), (Terj. Tri Wibowo: Psikologi Pendidikan). Jakarta: Prenada Media Group.

Shicida, Makoto. 1993. Right Brain Education in Infancy (Terj. Femi Olivia: Pendidikan Otak Kanan untuk Bayi, 2013). Jakarta: PT Elex Media Komputindo, Kelompok Gramedia.

Sims, Ronald R. \& Sims, Serbrenia J. 1995. The Importance of Learning Styles; Understanding the Implications for Learning, Course Design, and Education. London: Greenwood Press.

Solso, R.L. 1995. Cognitive Psychology. Washington DC: Winston: The Loyola Symposium. 
Sousa, David A. 2009. How The Gifted Brain Learns (Ed. Ke-2). (Terj. Dr. Ati Cahayani: Bagaimana Otak yang Berbakat Belajar, 2012). Jakarta: PT Indeks.

Trays, Rebeca. 2004. Understanding Your Brain. (Terj. Wasi Dewanto: Mempelajari Otak), Klaten: Pakar Raya Pustaka.

Windura, Sutanto. 2008. Brain Management. Jakarta: Elex Media Komputindo 